\title{
Development of a knowledge base to support the consideration of groundwater protection in land-use planning
}

\author{
Jérôme Cerutti ${ }^{1 *}$, Roxane Lavoie ${ }^{1}$ and René Lefebvre ${ }^{2}$ \\ ${ }^{1}$ École supérieure d'aménagement du territoire et de développement régional (ESAD), Université Laval, Pavillon Félix-Antoine- \\ Savard - FAS 1616, 2325 allée des Bibliothèques, Québec (QC), G1V 0A6, Canada. \\ ${ }^{2}$ Institut national de la recherche scientifique (INRS), Centre Eau Terre Environnement, 490 rue de la Couronne, Québec (QC), \\ G1K 9A9, Canada. \\ *Corresponding author. ORCID: 0000-0002-1162-9299; Tel.: +1 (418) 656-2131:4788; E-mail address: \\ jerome.cerutti.1@ulaval.ca
}

\begin{abstract}
Groundwater is an essential resource for water supply, but it is vulnerable to the potential impacts of contaminant emissions from human activities. It is widely recognized that the effects of human activities on groundwater quality and quantity can be mitigated, in large part, by appropriate landuse planning because it plays a central role in groundwater protection and conservation. However, groundwater-related issues are not commonly considered in the land-use decision-making process. The main objective of this paper was to develop a decision-support system (DSS) to fill the gap between groundwater resources management, territorial development and the land-use institutional framework. To achieve this objective, it was necessary to establish a dialogue with decision makers to identify their needs. Then, by linking human activities and their related contaminants and impacts, it was possible to identify land-use planning actions that could support groundwater protection. This research resulted in a tool named "Base de connaissances - aménagement du territoire et eau souterraine” (BC-ATES) [Knowledge base - Land use planning and groundwater]. This tool was tested using Microsoft Access. It includes all the information identified as relevant by land-use planners in the decision process regarding groundwater needs.
\end{abstract}

\section{Keywords}

Land-use planning; groundwater management; decision-support system; knowledge/data base.

\section{Acknowledgements}

Authors wish to thank land-use planners from the regional county municipalities of Appalaches, l'Islet, Lotbinière, Montmagny and Nouvelle-Beauce for participating in the development of an adapted tool for land-use planners. We also thank François Lajoie from the Organisme de Bassin Versant de la Côte-du-Sud for his help in recruiting participants. We acknowledge Sonja Behmel and Hervé Dandjinou from Watershed Monitoring for their precious help in building and validating the database. We also acknowledge the Réseau québécois sur les eaux souterraines (RQES) and l'Institut national de la recherche scientifique (INRS) for information on their groundwater data and groundwater research methodology. This research project was funded by the Centre de recherche en aménagement et en développement (CRAD) of Laval University, Quebec City (QC), Canada. 


\section{Introduction}

The use of groundwater resources for water supply is widespread. Compared to surface water, groundwater offers many advantages in terms of quality and quantity (Gleeson et al. 2010; Zektser et al. 2004). For example, groundwater supplies drinking water to more than $37 \%$ of the US population (estimated by Maupin et al. 2014) and more than 75\% in Europe (European Union et al. 2008). In the province of Québec, Canada, 20\% of the population depends on groundwater for their water supply (MDDELCC 2015). Furthermore, the use of groundwater resources is common for industrial activities and agriculture (Zektser et al. 2004).

However, groundwater faces many pressures from human activities (e.g., Changming et al. 2001; Custodio 2002; Gleeson et al. 2010; Trabelsi et al. 2005). Indeed, it is sensitive to overexploitation and vulnerable to potential contamination by surface activities (Granato and Smith 2002). Moreover, its regeneration capacity is slow and this aggravates the pollution impacts on a resource for which the assessment of quantity and quality is already complex and costly (Zektser et al. 2004). Thus, terrible consequences could occur when a groundwater supply is contaminated. One example in the province of Ontario (Canada) is the contamination of Walkerton's municipal groundwater supply by E. coli bacteria in May and June 2000. It was a public health disaster with 7 deaths and 2,300 people infected in a municipality with about 5,000 inhabitants (Driedger et al. 2014; Hrudey et al. 2002; Mullen et al. 2006; O’Connor, 2002). The economic impact of this tragedy was estimated at CDN \$64.5 million (Livernois 2002; Vicente and Christoffersen 2006). Because the bacteria from agricultural activities were spread by floods, this example points to the need for better land-use planning to adequately protect groundwater upstream of its withdrawal.

Indeed, as early as 1991, UNESCO issued a warning regarding the decline in groundwater quality resulting from inadequate land-use planning (Vrba et al. 1991). Several authors demonstrated a causal link between human activities and the quality and quantity of groundwater, including case studies (Collin and Melloul 2001; Conacher 1994; Foster and Cherlet 2014; Foster 2001; Haase 2009; Hayashi et al. 2009; Lerner and Harris 2009; Onodera et al. 2008; Scanlon et al. 2005; Tang et al. 2005; US EPA 2013). Yet, the integration of groundwater into land-use decision making continues to lag behind in the province of Québec, Canada (Caron et al. 2016; Lavoie, 2013). The problem persists, despite the existence of a regional groundwater resources assessment program (Programme d'acquisition de connaissances sur les eaux souterraines [PACES]) that covered more than 75\% of municipal land in Québec between 2009 and 2015 (MDDELCC 2015; RQES 2012). There are many reasons for this lack of integration of available data: inadequate human and financial resources; lack of cooperation between the water stakeholders; and, available hydrogeological data too technical and not adapted to the needs of land-use decision makers (Lavoie 2013). This echoes Armstrong's (1990) assertion that groundwater data have been collected on a large scale, but from a variety of independent sources and organized without links that could exist between them. Accordingly, these databases fail to answer the multidisciplinary problem of groundwater management and, de facto, are of little use to decision makers. 
Thus, the current situation may be summarized as follows: there are available data on groundwater resources in Québec, a dynamic land-use framework exists, and groundwater supplies a large part of the population. The question that must then be asked is how might we interconnect the information to help land-use planners develop their territory while minimizing the potential risk of pollution of their main source of drinking water? The aim of this study was to develop a decision-support tool in a relational database management system (RDBMS) that could be applied to a multidisciplinary activity such as land-use planning and groundwater protection. The model introduced by Codd (1970) is still the standard in databases. It is a collection of logically connected data without redundancy (Gabillaud 2009) that allows the storage of data and links, but also the manipulation and interrogation of the data while ensuring their protection, backup and access (Akoka and Comyn-Wattiau 2001; Favennec 1998; Nguyen and Meier 2006; Ponniah 2003; Welling and Thomson 2009). These advantages appear to have been adapted, since land-use planners do not have the time to develop a database from scratch, but do have the time to modify and use a database in their daily practice.

\section{Design}

\subsection{Description of the case study}

This study is part of a research project undertaken in the Chaudière-Appalaches region located to the South of Quebec City (province of Québec, Canada), which deals with the integration of groundwater into land-use planning. Groundwater data in this region were derived from a regional groundwater resources assessment program (Programme d'acquisition de connaissances sur les eaux souterraines [PACES]) supported by the Government of Québec between 2009 and 2015, with projects in different areas carried out by universities (INRS in the case of ChaudièreAppalaches) in collaboration with regional water stakeholders. The purpose of this program was to provide a picture of groundwater resources across municipal land in Québec. Data were published in the PACES-Chaudière-Appalaches (PACES-CA) project report in March 2015 (see Lefebvre et al. 2015). This PACES project covered the entire Chaudière-Appalaches region (excluding the city of Lévis), an area of 15,601 km².

Figure 1: Maps of the Chaudière-Appalaches study area showing:(a) Topography represented by the digital elevation model (DEM) (Lefebvre et al. 2015, p.9); (b) regional rock aquifer confinement conditions (based on the nature and thickness of surficial sediments) (Lefebvre et al. 2015, p.92); (c) recharge of the regional rock aquifer (Lefebvre et al. 2015, p.108), (d) Vulnerability of the regional rock aquifer based on the DRASTIC index (Lefebvre et al. 2015, p.116) 
The Chaudière-Appalaches region comprises three hydrogeological contexts: the St. Lawrence Lowlands, the Appalachian Valleys and the Appalachian Highlands. The topography of the area varies between $0 \mathrm{~m}$ to $1043 \mathrm{~m}$ (Figure 1a). The region is characterized by a continuous regional aquifer formed by naturally fractured rock and some local granular aquifers. Over most of the area, the regional rock aquifer is unconfined, but confined conditions are dominant in the St. Lawrence Lowlands (Figure 1b). The average annual recharge of the fractured rock aquifer is $166 \mathrm{~mm} /$ year (Figure 1c), with recharge far exceeding the groundwater exploitation rate, which is generally less than $10 \%$ of recharge except in some municipalities where it exceeds $20 \%$ in the St. Lawrence Lowland. The maximum DRASTIC vulnerability index (Aller et al. 1987) is between 160 and 180, which is considered as a medium to high vulnerability (Figure 1d). With a maximum of 168, the aquifers in the area does not reach a very high vulnerability. The most vulnerable areas are found where the aquifer is unconfined (Figure 1b) and has a high recharge (Figure 1c). Groundwater is also an important part of water supply in the region. Nearly $42 \%$ of the water used comes from groundwater and $32 \%$ of the population is supplied by private wells. Furthermore, nearly $60 \%$ of municipal systems are supplied by groundwater.

From an institutional and land-use planning perspective, the Chaudière-Appalaches region is made up of nine regional county municipalities (Municipalité régionale de comté [MRC]) comprising 135 municipalities with a total population of 278,234 inhabitants (MAMROT, 2016). The region is predominantly rural and farming occupies two thirds of the inhabited area (Services Québec, 2015). As part of this research, five MRC land-use planners (regional stakeholders) volunteered to participate in the development of the decision support tool (Table 1). Their interest in participating in this research stems mainly from the recent availability of groundwater data covering their region, but also from a lack of available tools to consider groundwater in land-use planning.

Table 1-Portrait of participating regional county municipalities (MRC). (Data: final report and deliverable 26B of PACES-CA, 2015; MAMROT, 2016).

Based on the methodological examples of Connolly and Begg (2005), Akoka and ComynWattiau (2001), and some elements of Ponniah (2003), the design of the knowledge base was completed in three phases: conceptual, logical and physical. The main classes of the knowledge base were first developed, followed by secondary classes. Classes are data tables that group information categories (attributes) composed by data. For example, the class "Reference" is composed of attributes such as the name of the document used, the name of the organization that created the document and its year of publication. To identify this information, the participation of regional stakeholders was continuous and represents a benefit for this study. Indeed, the meetings with stakeholders made it possible to learn more about their relationship with groundwater resources found within their territory. Furthermore, the discussions also identified their needs and expectations in order to make the tool as functional as possible.

\subsection{Conceptual design}




\subsubsection{Identifying the purpose of the tool and its potential uses}

First, this study defined the basis of the tool (purpose and uses). Its purpose is to reduce the impact of human activities on groundwater through sustainable land-use planning (Figure 2).

Figure 2 - Dynamics considered to reduce the impact of human activities on groundwater resources through land-use planning

Then, three purposes for the tool were identified through exchanges with the participating regional stakeholders. Two of the purposes concern actions taken to prevent contamination; the third purpose is in response to a proven problem (Figure 3).

Prevention: If the regional or local authorities had projects and developments that they would like to implement within their territory, they would use the knowledge base to:

- Identify the activity that represents the lowest risk or the most tolerable potential impact on groundwater resources.

- Identify the measures to be implemented during the development of a project to reduce potential impacts on groundwater.

Reaction: If the regional or local authorities observed any degradation of groundwater quality (on infrastructure, in the environment, etc.), they would use the knowledge base to:

- Identify the probable sources of contamination by identifying activities releasing this type of contaminant.

Figure 3 - The purposes of the tool: Prevention and reaction illustrated by the example of vegetable farming

\subsubsection{Identification of Primary, Secondary and Attribute Classes}

After the identification of the purpose and uses of the tool, key elements emerged and were used to define the different classes of the tool. For example, the need for knowledge about the available action tools or the actors at the origin of the classes "Tool" and "Actor". The identification process of the tool classes was achieved during individual meetings with participating regional stakeholders. This process was carried out from the inside out, starting with primary classes - considered as absolutely necessary by stakeholders-, followed by secondary classes - considered as interesting information—, and including the "PACES" classes that make a link between tool and the data from the governmental program (Figure 4). For validation, identified key elements were regrouped and sent by email to stakeholders. Through discussions and consensus between all stakeholders, primary and secondary class were thus validated.

Figure 4-The twelve classes identified for the tool 
The primary classes are:

- "Actor": lists the actors who have the legal competence or who participate in the implementation of an action. These actors are government agencies and organizations, the population, but also private companies. The information comes from provincial laws and regulations, ministerial directives and examples of actions implemented by other regional or local stakeholders at the provincial scale.

- "Action": lists actions that the land-use planner could implement to avoid or correct a case of contamination. These actions are identified through legislative sources, ministerial directives and planning documents at the provincial scale.

- "Activity": identifies the activities present in the territory on the basis of the land-use code (Code d'utilisation des biens-fonds, CUBF) from Québec's property assessment manual (Manuel d'évaluation foncière du Québec [MAMROT 2010a]) edited by the provincial government. This kind of property codification is the key to making this tool work. The CUBF takes the physical and economic inventory of the provincial territory by identifying its different uses (MAMROT 2010b). The CUBF has different degrees of accuracy from one to four digits. Each usage has a unique four-digit code. For example, the code CUBF 1542 corresponds to the use "orphanage" categorized in 154 "House of retreat and orphanage", in Category 15 "dwelling in common", all classified in the use Type 1 "residential". In order for the tool to be adapted to day-to-day practices, meetings with landuse planners concluded that the four-digit CUBF code was the most accurate level of precision regarding human activities.

- "Impact": identifies the potential impact of contaminants categorized by types of impacts (infrastructure, environment, human health, etc.). This information was identified through various sources, such as governmental health agencies or the scientific literature.

- "Contaminant": identifies the main contaminants that can be found in groundwater. The data from PACES Protocol 23 are used to produce an index of the density of potentially groundwater-polluting human activities (Audet-Gagnon et al. 2013). The aim of this protocol is to assess the potential impact of anthropogenic activities in terms of the perceived risk on the quality of groundwater resources.

- "Tool”: lists the tools with which actions can be implemented, such as awareness raising, financial incentives and fines, planning documents and legal regulations. These tools were identified through the provincial legislation and examples of actions were based on other regional or local stakeholders at the provincial level.

Secondary classes are used mainly to add information. It is possible to subdivide the secondary classes into sub-classes resulting from PACES Protocol 23. The level of threat to groundwater quality represented by a CUBF activity is calculated according to PACES protocol 23 as follows: potential impact (class "Risk") = (toxicity of contaminants [class "Toxicity"] + quantity of contaminants [class “Quantity”] + activity area of impact [Class “Zone”]) $\times$ recurrence of contaminant releases (class “Recurrence”) (Audet-Gagnon et al. 2013). The knowledge base does 
not allow users to calculate the risk. It serves only to integrate the information produced by the protocol to inform land-use planners. Secondary classes include:

- "Reference": lists examples of the implementation of actions and the legal documents used as a basis for the action. These are planning documents from regional and local land-use planners having implemented the same action, or a similar action. "Reference” also contains articles of law requiring the implementation of certain actions, or ministerial directives that advise on the implementation of these actions.

- "Toxicity": indicates the toxicity of contaminants associated with an activity. PACES Protocol 23 uses the toxicity classification of pure products listed in an information system for hazardous materials in workplaces (Système d'information sur les matières dangereuses utilisées au Travail, SIMDUT) developed by the provincial government. Pure products are classified under three sub-categories according to their quantity in the contaminant. For each of the three products, they are categorized as nontoxic, toxic or very toxic.

- "Quantity": indicates the quantity and concentration of contaminants associated with the activity. The quantity of contaminants can be small, large, or very large. Contaminant concentration may be low, medium or high.

- "Zone": refers to the potential impact area of the activity. It is subdivided into three spatial scales: punctual $\left(10 \mathrm{~m}^{2}\right)$, local $\left(100 \mathrm{~m}^{2}\right)$ and regional $\left(1 \mathrm{~km}^{2}\right)$.

- "Recurrence": indicates the potential contamination of an activity over time. If the releases are systematic and related to the nature of the activity, they are considered as recurrent. In other cases, they are considered as accidental.

- "Risk": indicates the potential impact of each CUBF activity on the quality of groundwater. Activities are divided into four risk classes: low, moderate, high, very high.

Following the identification of the different classes that make up the knowledge base, the attributes of each class were defined (Appendix 1). Finally, the validation of the attributes within the classes was carried out with participating land-use planners through emails.

\subsection{Logical design}

During the logical design, the associations - link - and the multiplicity - how the elements are linked - between each class were identified. Figure 5 illustrates those elements using an example (vegetable farming). This phase was carried out in three parts to ensure better readability.

\section{Figure 5: Associations ("Links") illustrated with the example of the activity "Vegetable Farming”}

The purpose of the first part (non-illustrated in Figure 5) was to establish a link between the PACES and the activities inside the database. All the PACES classes are characterized by aneto-many multiplicity with the class “Activity”. For example, a degree of risk may involve several activities, but an activity can only be associated with a single degree of risk. A “Moderate risk" is 
associated with activities such as "Vegetable farming", "Lumbering industry" or "Golf course", but "Vegetable farming" is only associated with "Moderate" risk and not "Very High", "High" or "Low" risk.

The purpose of the second part was to link the activities and the solutions (actions) through the causalities made by the contaminants. Each association between these classes is characterized by a many-to-many multiplicity. For example, "Vegetable farming" is associated with contaminants such as "Nitrate", "Phosphate" or "Coliform and non-coliform bacteria". "Nitrate" is also associated with other activities such as "Chalet or vacation house" or "Cereals, oilseed and leguminous plant crops". The same logical process was repeated for each element to establish association and multiplicity between them.

The purpose of the third part was to link the solutions to the right tools and actors. Each association is characterized by a many-to-many multiplicity. For example, an action may be implemented by several tools and a tool can implement several actions.

Finally, the verification and validation of the links between classes were carried out with database professionals during dozens of meetings. The objective was to identify on paper the problems that could occur before implementing the concept in the database management system. Moreover, this step aimed to be sure about the logical construction of the concept.

\subsection{Physical design}

The physical design served to identify the type (numerical, textual, etc.) of each attribute. These elements are presented in Appendix 2. The knowledge base was validated during meetings with database experts to ensure that all the concept did not contain logical mistakes and to verify if the links between classes were well designed. Then the concept was implemented according to the model shown in Figure 6, which illustrates how the previously described blocks fit together.

Figure 6 - The BC-ATES physical implementation model

\section{Application}

Results of the design produced the "Base de connaissances - Aménagement du Territoire et Eau Souterraine" (BC-ATES) [Knowledge base - Land use planning and groundwater] decision support tool. To test the decision-support system, it was implemented in the Microsoft Access software.

\subsection{The choice of data}


During meetings, regional stakeholders were asked to identify the activities they would like to see in the knowledge base test (Table 2). Participants highlighted agricultural activity, which represents a large part of the land-use present within their territories. Then, other elements that could have an impact on groundwater in their territories were discussed, such as resorts, oil pipelines, industries, golfs, logging, and the road network. Thus, we can consider that these elements represent as many territorial realities as elements of concern for the regional stakeholders. According to the wishes of stakeholders, twelve activities were selected based on three criteria: the activity had to exist in at least two of the five regional county municipalities; the potential risk of the activity; and, its impact area. For the potential risk and the impact area, the selected activities had to be as heterogeneous as possible in order to provide a variety of scenarios to the knowledge base. The presence of the activities was noted through land-use planning documents and economic portraits of the region; the risk and the impact area were identified by PACES Protocol 23 as previously described.

Table 2 - The twelve activities selected for the BC-ATES test

Following the choice of activities, all the data were inserted sequentially for one activity at a time. For the 12 activities, it was possible to identify 24 actions, 16 actors, 33 contaminants, 25 impacts and 22 tools (Appendix 3).

\subsection{Information Filtering}

After implementing information inside the knowledge base, the first queries - a request for information from a database - revealed that the information had to be filtered. Indeed, to avoid inexact information in the results of the query, specific criteria (the filters) had to be added inside the query. For example, it is necessary to filter the information for activities releasing the same contaminating product and having the same impact in order to obtain the appropriate action to apply to the activity. For instance, the action of "Reduce the spread of de-icing salt" should not concern the activity "Vegetable farming". Thus, two filters must be inserted to correctly identify the Activity-Action and Activity-Actor combination (Figure 7). These filters may take many forms and can be inserted directly into coding. However, as part of this research, they were implemented in Microsoft Access by adding the "Code_CUBF" attribute in the "Action" and "Actor" classes. These attributes allowed to create associations between the classes and acted as filters. As a list of choices, this attribute retrieves the information from the "Activity" class and makes it possible to associate an activity with an action and an activity with an actor.

Figure 7 - Illustration of the use of query filters inside the tool.

\subsection{Access to information}


After formatting and implementing the knowledge base, access to information was put in place. After meetings with regional stakeholders, a form was developed within the knowledge base to gain access to the information (Appendix 4). The first version of the form consisted of dropdown lists and search fields, which only allowed the user to browse the information with no possibility to modify or creating data inside the knowledge base. Therefore, it could only be used to query information and minimize the risk of untimely changes made to the data.

In the first part of the form, in a fixed header, water stakeholders can quickly find general information about activities such as the code of the activity (attribute "Code_CUBF"), the category of the activity (attribute "Category_CUBF"), the name of the activity (attribute "Name_Activity") and the level of risk linked to the activity (class "Risk_Codification"). Users can search for an activity by its code CUBF or by its name. Using a fixed header allows users to scroll down the page without losing sight of the activity to which the data relate.

Then, in the second part of the form, users have the final part of the general information about the activity such as the frequency of contaminant releases (attribute "Frequency_Name") and the impact area of the activity (attribute "Name_Impact_Zone"). Two main tables are visible through sub-forms. First, the contaminants rejected by the activity and their impacts (class "Contaminant"). Inserted as a sub-sub-form, users have details regarding identified impacts (class "Impact") for each contaminant. Then, another sub-form makes the synthesis of all the impacts (class "Impact") linked to the activity.

Lastly, in the third part of the form, information about land-use planning actions and how to implement them are shown. The same process of sub-sub-form is reproduced as this process allows precise access to information. A sub-form listing the actions (class "Action") is inserted, allowing users to have a clear and quick information about all the actions that can be implemented regarding the activity. Then, a first sub-sub-form indicates which tool (class "Tool”) is necessary to implement the action and, for each action, it is possible to consult the various tools available. Finally, the second sub-sub-form indicates the actor (class "Actor") that is legally responsible or related to the tool necessary to implement the action.

Thanks to filtering, the information from the form, sub-form and sub-sub-form allows users to find the right actions to implement according to the activity sought. Moreover, when it comes to awareness, the actors are filtered according to their competence with regard to the activity.

\section{Discussion}

One of the most important issues in the development of BC-ATES was the identification of the most relevant stakeholder who might use the knowledge base. The choice was directed towards regional county municipalities (MRC) for three reasons. First, MRCs are at the crossroads between the ministries (who make the decisions) and the municipalities (which have most of water 
competencies). Secondly, the ministerial level is too far removed from local realities and the municipal level cannot act outside its administrative boundaries. Thirdly, municipalities would not have had sufficient financial and human resources to use such a tool. The second challenge was to identify the easiest tool that spatial planners could use. Relational database management systems (RDBMS) were chosen because they offer flexibility which, as part of this study, enables the effective link between information from the territory, the groundwater resources and the land-use institutional framework. Thus, land-use planners have quick access to the information they need concerning the potential impact of activities on groundwater. However, many limitations were identified.

The most important limitation of BC-ATES is the need to have a land-use planning institutional framework and a property codification, without which it would be impossible to adjust this tool. Another main limitation is the availability of groundwater data and the knowledge transfer of these data to land-use planners. Indeed, such a tool requires programs producing knowledge on groundwater resources that have been carried out previously. In Québec, the PACES has produced such knowledge in most regions, including the test region used to develop the tool. This implies a significant investment by governmental agencies. Moreover, even after obtaining the data on the resource, it is necessary to efficiently transfer the knowledge to water stakeholders who must exploit these complex hydrogeological data. In Québec, a groundwater knowledge transfer program was initiated in 2014. By 2018, it will have covered all regions where PACES projects have previously been carried out (RQES 2016). Another limitation is the need to continuously update the knowledge base. Indeed, the institutional framework is in constant evolution and the tool must be dynamic to be relevant in the long term. Thus, this implies that human resources must be allocated to update the tool. The last limitation regards aspects such as mentalities towards groundwater resources that are struggling to evolve or the lack of political will which hampers the use of such a tool. Indeed, protection and conservation of groundwater can be seen as a constraint on the development of municipalities, even though groundwater resources often represent an important part of their water supply.

Finally, the knowledge base could be enriched by the integration of economic components such as the cost of the actions and the quantification of the economic losses due to the pollution of the water resources. During meetings with the MRCs, the addition of an economic variable was requested in order to support action proposals presented to elected representatives. However, given the complexity of integrating economic components, it was proposed to integrate similar implementation examples offering an idea of the costs of an action. Furthermore, the association class linking the "Contaminant" and "Impact" classes could contain a "Reference" attribute that would allow the user to know where the information originates from.

\section{Conclusion}


The objective of this research was to develop a decision-making support tool to fill the gap between information about groundwater resources, territorial development and the institutional framework of land-use planning. To achieve this objective, three major methodological steps were followed to develop a decision support system. First, a conceptual design identified the purpose of the tool, its uses and the content of the primary classes, secondary classes and attributes. This was followed by a logical design to identify the associations and the multiplicity between each class. In other words, this stage made it possible to identify the links between the classes. Finally, a physical design identified the type of each attribute within the class. The result of this research is a tool known as "Base de connaissances - Aménagement du Territoire et Eau Souterraine" (BCATES) [Knowledge base - Land use planning and groundwater]. BC-ATES was tested using Microsoft Access software.

The development of BC-ATES would not have been possible without the participation of land-use planners from the Chaudière-Appalaches region. Indeed, as regional stakeholders, their participation was crucial to the conceptual design and different stages of validation. Thanks to their help, it was possible to adapt the tool as closely as possible to their land planning practices. Furthermore, the participation of database professionals resulted in the development of a userfriendly tool.

BC-ATES faces some limitations. Indeed, for the development of such a decision-making tool, a land-use planning framework is crucial, as is the existence of groundwater information. Furthermore, the tool must be updated continuously. This limitation is important because it involves identifying the organization responsible for these updates and setting aside the necessary resources to work on the updates. Finally, this type of tool can faces political and social obstacles, which would limit its usefulness.

Despite these limitations, BC-ATES is a promising tool because it integrates, in one location, a set of information that can help land-use planners to consider groundwater in their planning. Not only is BC-ATES making users aware of the source of groundwater contamination, but it also proposes solutions through actions that can be implemented in land-use planning to prevent or reduce contamination. Moreover, BC-ATES indicates the legal tool with which it would be possible to implement an action, as well as the actor having the legal competence to carry out the action. Therefore, this tool offers significant potential to help protect and conserve groundwater in the context of land-use planning. 


\section{Bibliography}

Akoka J, Comyn-Wattiau I (2001) Conception des bases de données relationnelles [Designing relational databases]. Vuibert informatique, Paris

Aller L, Bennett T, Lehr JH, Petty R, Hackett G (1987) DRASTIC: A Standardized System for Evaluating Ground Water Pollution Potential Using Hydrogeologic Settings. National Water Well Association, Dublin, OH, USA

Armstrong MP (1990) Database integration for knowledge based groundwater quality assessment. Computers, Environment and Urban Systems 14:187-201. doi: 10.1016/0198-9715(90)90008-H

Audet-Gagnon F, Roy M, Ballard J-M, Carrier M-A (2013) Protocole pour la préparation du Livrable 23 - Indice de densité d'activités anthropiques. (Programme d'acquisition de connaissances sur les eaux souterraines du Québec) [Protocol for the preparation of Deliverable 23 - Density index of anthropogenic activities. (Québec's regional groundwater resources assessment program)]. Université du Québec en Abitibi-Témiscaminque (UQAT) en collaboration avec l'Institut national de la recherche scientifique, Centre - Eau Terre Environnement (INRSETE)

Caron S, Cerutti J, Marleau Donais F, Vallières L (2016) Eau souterraine : une planification à la source de la protection [Groundwater: land-use planning at the source of its protection]. Dissertation, Université Laval

Changming L, Jingjie Y, Kendy E (2001) Groundwater Exploitation and Its Impact on the Environment in the North China Plain. Water International 26:265-272. doi: $10.1080 / 02508060108686913$

Codd EF (1970) A relational model of data for large shared data banks. Communications of the ACM 13:377-387. doi: 10.1145/362384.362685

Collin ML, Melloul AJ (2001) Combined land-use and environmental factors for sustainable groundwater management. Urban Water 3:229-237. doi: 10.1016/S1462-0758(01)00049-8

Conacher AJ (1994) The integration of land-use planning and management with environmental impact assessment: some Australian and Canadian perspectives. Impact Assessment 12:347-372. doi: 10.1080/07349165.1994.9725874

Connolly TM, Begg CE (2005) Systèmes de bases de données : approche pratique de la conception, de l'implémentation et de l'administration [Database Systems: A Practical Approach to Design, Implementation and Administration]. Éditions Reynald Goulet, Repentigny, Québec 
Custodio E (2002) Aquifer overexploitation: what does it mean? Hydrogeology Journal 10:254277. doi: 10.1007/s10040-002-0188-6

Driedger SM, Mazur C, Mistry B (2014) The evolution of blame and trust: an examination of a Canadian drinking water contamination event. Journal of Risk Research 17:837-854. doi: 10.1080/13669877.2013.816335

European Union, European Commission, Directorate-General for the Environment (2008) Protection des eaux souterraines en Europe: la nouvelle directive sur les eaux souterraines : une consolidation du cadre réglementaire de l'UE [Groundwater protection in Europe: the new groundwater directive: consolidation of the EU's regulatory framework].

Favennec J-P (1998) Raffinage du pétrole (Le) [Oil refining]. Tome 5. Exploitation et gestion de la raffinerie. Editions TECHNIP

Foster S, Cherlet J (2014) The links between land use and groundwater - Governance provisions and management strategies to secure a "sustainable harvest." Global Water Partnership

Foster SS. (2001) The interdependence of groundwater and urbanisation in rapidly developing cities. Urban Water 3:185-192. doi: 10.1016/S1462-0758(01)00043-7

Gabillaud J (2009) Oracle 11g: SQL, PL/SQL, SQL*Plus. Editions ENI

Gleeson T, VanderSteen J, Sophocleous MA, et al (2010) Groundwater sustainability strategies. Nature Geoscience 3:378-379. doi: 10.1038/ngeo881

Granato GE and Smith KP (2002) Robowell — Providing Accurate and Current Water-Level and Water-Quality Data in Real Time for Protecting Ground-Water Resources: US Geological Survey Fact Sheet FS-053-02:6. In: USGS. https://pubs.usgs.gov/fs/fs05302/robo.htm

Haase D (2009) Effects of urbanisation on the water balance - A long-term trajectory. Environmental Impact Assessment Review 29:211-219. doi: 10.1016/j.eiar.2009.01.002

Hayashi T, Tokunaga T, Aichi M, et al (2009) Effects of human activities and urbanization on groundwater environments: An example from the aquifer system of Tokyo and the surrounding area. Science of The Total Environment 407:3165-3172. doi: 10.1016/j.scitotenv.2008.07.012

Hrudey SE, Huck PM, Payment P, et al (2002) Walkerton: Lessons learned in comparison with waterborne outbreaks in the developed world. Journal of Environmental Engineering and Science 1:397-407. doi: 10.1139/s02-031

Lavoie R (2013) Stratégies pour faciliter l’intégration de l'eau souterraine dans la prise de décision 
en aménagement du territoire [Strategies to facilitate the integration of groundwater in land-use planning decision-making]. Dissertation, Université Laval

Lefebvre R, Ballard J-M, Carrier M-A, et al (2015) Portrait des ressources en eau souterraine en Chaudière-Appalaches, Québec, Canada [A Portrait of groundwater resources in ChaudièreAppalaches, Québec, Canada]. Projet réalisé conjointement par l'Institut national de la recherche scientifique (INRS), l'Institut de recherche et développement en agroenvironnement (IRDA) et le Regroupement des organismes de bassins versants de la Chaudière-Appalaches (OBV-CA) dans le cadre du Programme d'acquisition de connaissances sur les eaux souterraines (PACES), Rapport final INRS R-1580, soumis au MDDELCC en mars 2015.

Lerner DN, Harris B (2009) The relationship between land use and groundwater resources and quality. Land Use Policy 26:S265-S273. doi: 10.1016/j.landusepol.2009.09.005

Livernois J (2002) The Economic Costs of the Walkerton Water Crisis. Ministère du procureur général, Toronto $(\mathrm{ON})$

Maupin MA, Kenny JF, Hutson SS, et al (2014) Estimated use of water in the United States in 2010. U.S. Geological Survey, Reston, Virginia

Ministère des Affaires municipales et de l'Occupation du territoire (MAMROT) (2010a) Manuel d'évaluation foncière du Québec [Québec's property assessment manual] (MEFQ). In: Ministère des Affaires municipales et de l'Occupation du territoire. http://www.mamrot.gouv.qc.ca/evaluation-fonciere/manuel-devaluation-fonciere-duquebec/edition-modernisee-depuis-2010/.

Ministère des Affaires municipales et de l'Occupation du territoire (2010b) Codes d'utilisation des biens-fonds [The land-use code]. In: Ministère des Affaires municipales et de l'Occupation du territoire. http://www.mamrot.gouv.qc.ca/evaluation-fonciere/manuel-devaluation-fonciere-duquebec/codes-dutilisation-des-biens-fonds/. Accessed 9 Aug 2016

Ministère des Affaires municipales et de l'Occupation du territoire (MAMROT) (2016) Répertoire des municipalités: $\mathrm{N}^{\circ} 12$ - Chaudière-Appalaches [Directory of municipalities : $N^{\circ} 12$ Chaudière-Appalaches]. In: Ministère des Affaires municipales et de l'Occupation du territoire. http://www.mamrot.gouv.qc.ca/repertoire-des-municipalites/fiche/region/12/. Accessed 13 Jun 2016

Ministère du Développement Durable, de l'Environnement et de la Lutte contre les Changements Climatiques (2015) Programme d'acquisition de connaissances sur les eaux souterraines (PACES) [Regional groundwater resources assessment program]. In: MDDELCC. http://www.mddelcc.gouv.qc.ca/eau/souterraines/programmes/acquisition- 
connaissance.htm\#premier.

Mullen J, Vladi N, Mills AJ (2006) Making Sense of the Walkerton Crisis. Culture and Organization 12:207-220. doi: 10.1080/14759550600865933

Nguyen DH, Meier A (2006) Introduction pratique aux bases de données relationnelles [Practical introduction to relational databases]. Springer Science \& Business Media

O’Connor DR (2002) Report of the Walkerton Inquiry. Ontario Ministry of the Attorney General, Ontario

Onodera S, Saito M, Sawano M, et al (2008) Effects of intensive urbanization on the intrusion of shallow groundwater into deep groundwater: Examples from Bangkok and Jakarta. Science of The Total Environment 404:401-410. doi: 10.1016/j.scitotenv.2008.08.003

Ponniah P (2003) Database Design and Development: An Essential Guide for IT Professionals. John Wiley \& Sons, Inc., Hoboken, NJ, USA

Réseau Québecois sur les Eaux Souterraines (RQES) (2012) Qu'est-ce-que les PACES? [What are the PACES?] In: RQES. http://rqes-gries.ca/fr/archives-et-documents/rapports-memoires-etcartes/260-quest-ce-que-les-paces.html. Accessed 27 May 2016

Réseau Québecois sur les Eaux Souterraines (RQES) (2016) La stratégie de transfert et d'échange de connaissances sur les eaux souterraines [The Groundwater Knowledge Transfer and Exchange Strategy]. In: rqes. http://rqes.ca/strategie-de-transfert-dechange-de-connaissances-eauxsouterraines/. Accessed 19 Jan 2017

Scanlon BR, Reedy RC, Stonestrom DA, et al (2005) Impact of land use and land cover change on groundwater recharge and quality in the southwestern US. Global Change Biology 11:15771593. doi: 10.1111/j.1365-2486.2005.01026.x

Services Québec (2015) Chaudière-Appalaches (12) - Portail Québec. In: Portail Québec. http://www.gouv.qc.ca/FR/LeQuebec/Pages/ChaudiereAppalaches.aspx. Accessed 13 Jun 2016

Tang Z, Engel BA, Pijanowski BC, Lim KJ (2005) Forecasting land use change and its environmental impact at a watershed scale. Journal of Environmental Management 76:35-45. doi: 10.1016/j.jenvman.2005.01.006

Trabelsi R, Zaïri M, Smida H, Ben Dhia H (2005) Salinisation des nappes côtières : cas de la nappe nord du Sahel de Sfax, Tunisie [Salinization of coastal aquifers : case of the northern Sahel of Sfax, Tunisia]. Comptes Rendus Geoscience 337:515-524. doi: 10.1016/j.crte.2005.01.010 
US EPA (2013) Our Built and Natural Environments: A Technical Review of the Interactions between Land Use, Transportation, and Environmental Quality (2nd edition). United States Environmental Protection Agency

Vicente KJ, Christoffersen K (2006) The Walkerton E. coli outbreak: a test of Rasmussen's framework for risk management in a dynamic society. Theoretical Issues in Ergonomics Science 7:93-112. doi: 10.1080/14639220500078153

Vrba J, Aldwell CR, Alfoldi L, et al (1991) Integrated Land-Use Planning and Groundwater Protection in Rural Areas: A Comparative Study of Planning and Management Methodologies. UNESCO, Paris

Welling L, Thomson L (2009) PHP et MySQL [PHP and MySQL]. Pearson Education France

Zektser IS, Everett LG, International Hydrological Program (2004) Groundwater resources of the world and their use. UNESCO, Paris 
Table 1-Portrait of participating regional municipalities (MRC). (Data: final report and deliverable 26B of PACES-CA, 2015; MAMROT, 2016).

\begin{tabular}{|r|cccc}
$\begin{array}{r}\text { Name of the } \\
\text { MRC }\end{array}$ & $\begin{array}{l}\text { Number of } \\
\text { municipalities }\end{array}$ & $\begin{array}{l}\text { Population } \\
(\mathbf{2 0 1 6})\end{array}$ & $\begin{array}{l}\text { Surface } \\
\text { area } \\
\left.\mathbf{k m}^{2}\right)\end{array}$ & $\begin{array}{l}\text { Groundwater } \\
\text { use (relative to } \\
\text { total water use) }\end{array}$ \\
\hline \begin{tabular}{r|cccc} 
Appalaches \\
L'Islet
\end{tabular} & 19 & 42970 & 1912,38 & $47,8 \%$ \\
Lotbinière & 14 & 18320 & 2098,80 & $72,1 \%$ \\
Montmagny & 18 & 31266 & 1663,49 & $67,1 \%$ \\
Nouvelle-Beauce & 14 & 22750 & 1692,84 & $39,1 \%$ \\
\end{tabular}

Table 2 - The twelve activities selected for the BC-ATES test

\begin{tabular}{|l|l|}
\hline $\begin{array}{l}\text { CUBF } \\
\text { codification }\end{array}$ & Name of the activity \\
\hline $\mathbf{1 1 0 0}$ & Cottage or vacation house \\
\hline $\mathbf{4 5 1 0}$ & Highways and streets \\
\hline $\mathbf{4 8 5 5}$ & Garbage dump \\
\hline $\mathbf{4 8 8 0}$ & Snow dump \\
\hline $\mathbf{5 8 1 1}$ & Restaurant and establishment with full service, without terrace \\
\hline $\mathbf{7 4 1 2}$ & Golf course, with chalet and other sports facilities \\
\hline $\mathbf{8 1 2 1}$ & Beef cattle breeding \\
\hline $\mathbf{8 1 2 2}$ & Dairy cattle breeding \\
\hline $\mathbf{8 1 3 2}$ & Cereal, oilseed and leguminous plant crops \\
\hline $\mathbf{8 1 9 9}$ & Vegetable farming \\
\hline $\mathbf{8 3 1 1}$ & Lumbering industry \\
\hline $\mathbf{8 5 1 1}$ & Iron ore mining \\
\hline
\end{tabular}




\section{Human activities and their contaminants}

\section{Impacts on groundwater}

Appropriate protection and conservation measures 


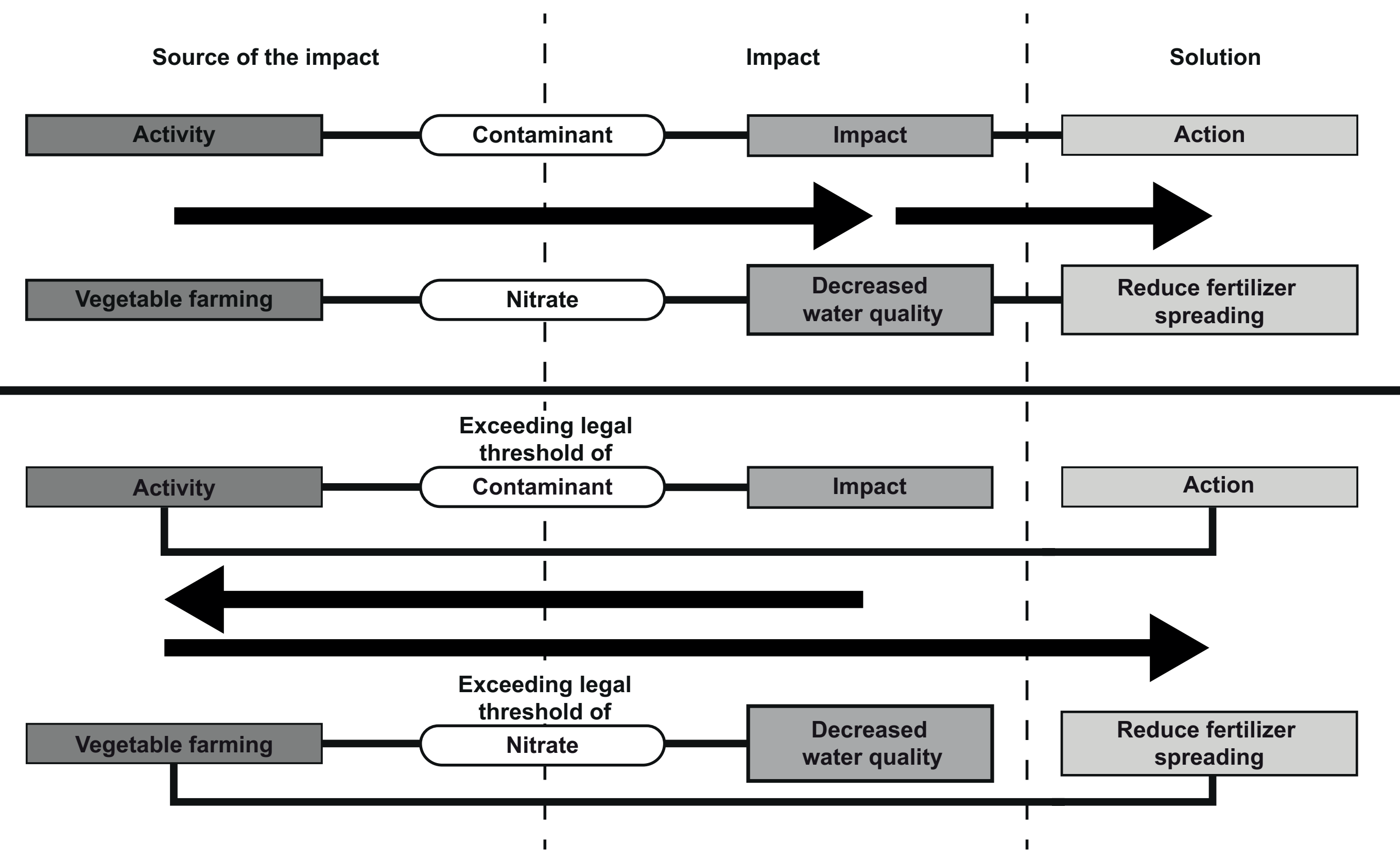


Primary Classes

Actor

Action

Activity

Contaminant

Impact

Tool
Secondary classes

I

$\begin{array}{lll}1 & 1 \\ 1 & 1 \\ 1 & 1\end{array}$

1
1

I

I I

11,

$1 \mathrm{I}$

Zone

Recurrence

Risk

\section{Reference}

PACES classes

\section{Toxicity}

\section{Quantity}
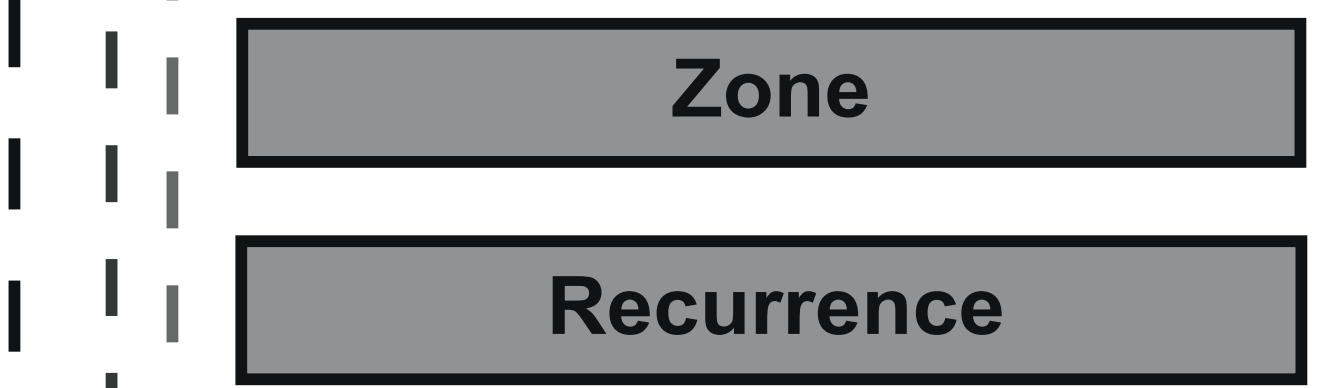

$\left|\begin{array}{l}\mid \\ \mid\end{array}\right|$

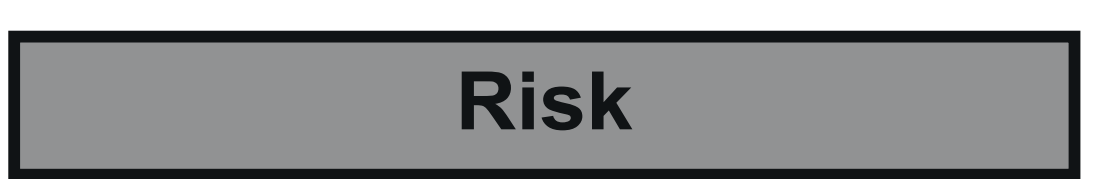

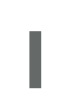

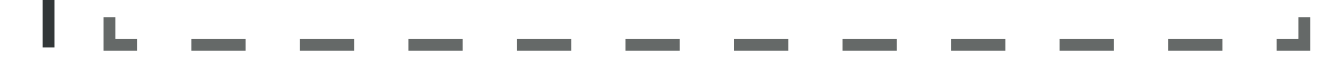

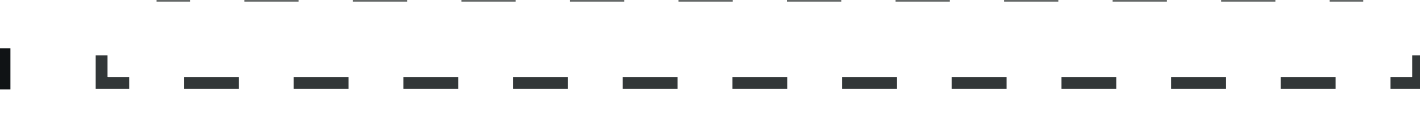


Vegetable farming

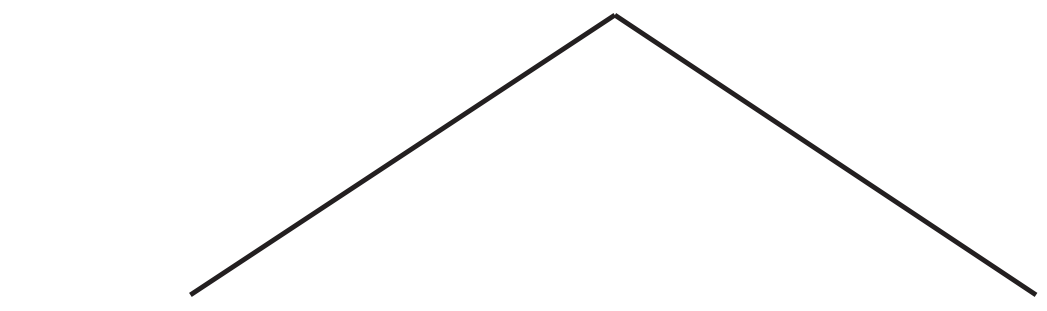

Contaminant 1

Nitrate

Contaminant 2

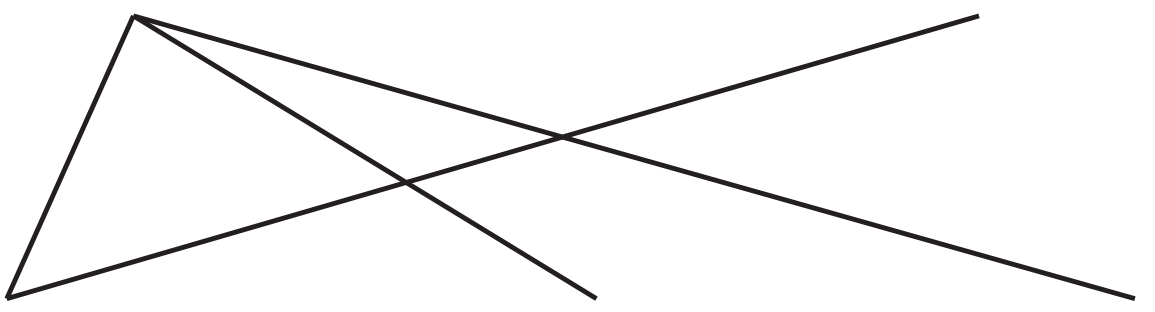

Impact A

Decline in water

Quality

Impact B

Corrosion of drinking water

distribution systems

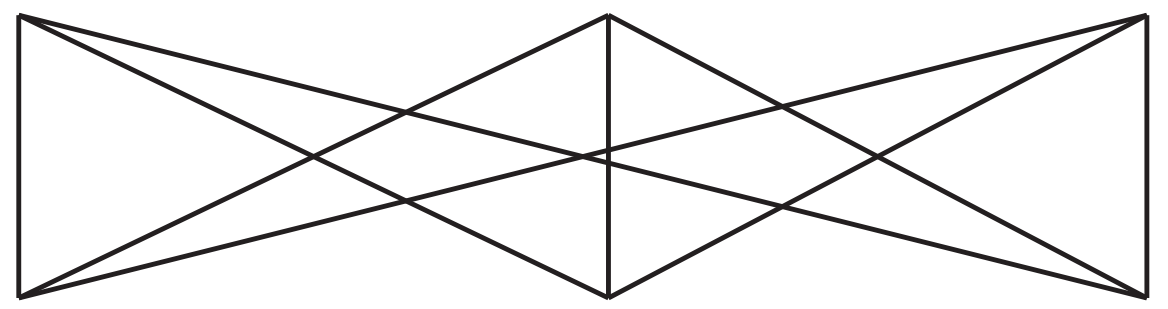

Action 1

Reduce the

spread of fertilizer
Action 2

Reduce the

spread of

de-icing salt
Impact C

Destruction

of the flora
Action 3

Manage

agricultural

waste

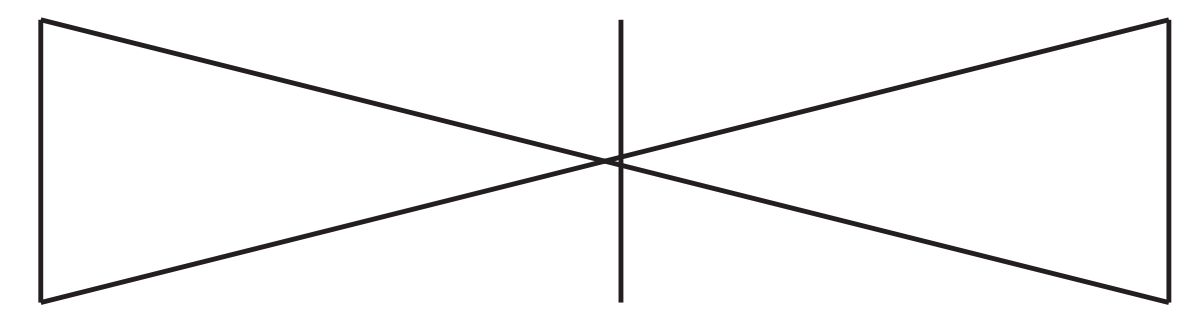

Tool 1

Agroenvironmental plan for fertilizers

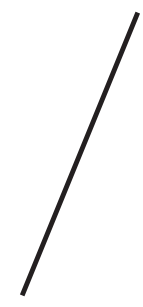

Actor A

Farmer
Tool 2

Salt Management Plan
Tool 3

Sensibilisation

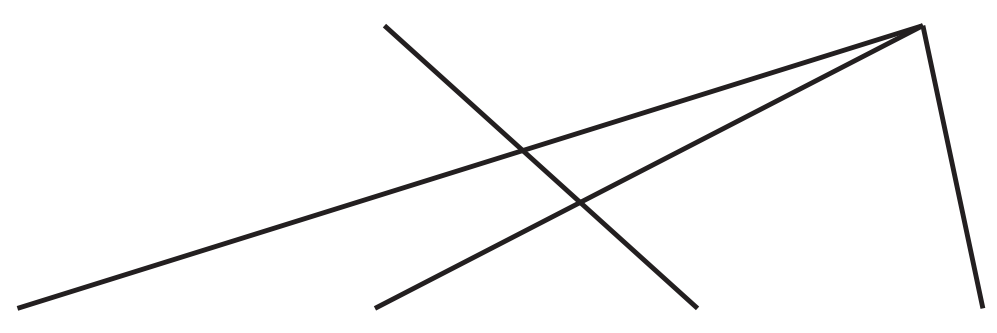

Actor B

Actor C

Actor D

Actor E Municipality MDDELCC MRC 


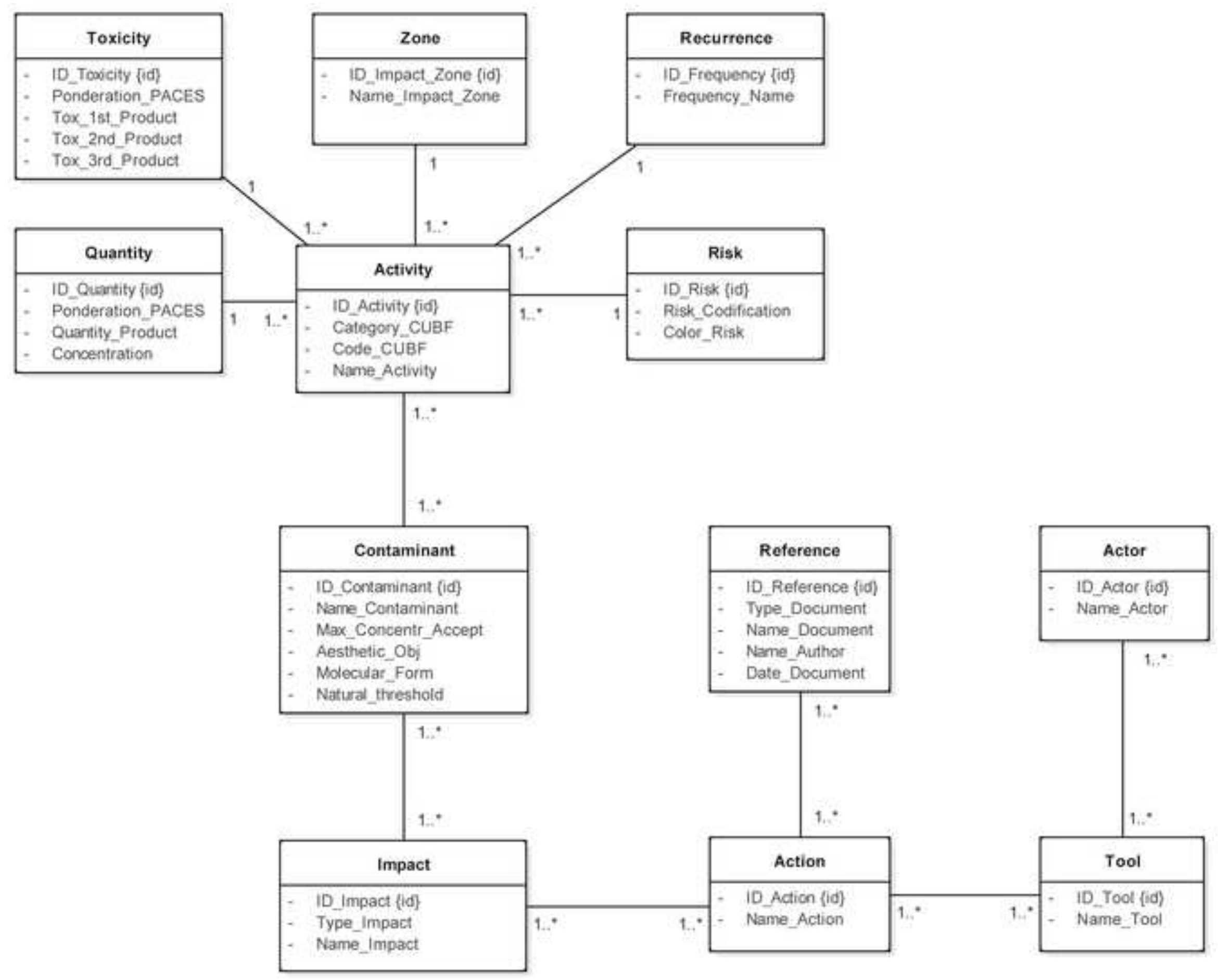


Figure 7 - Adobe Illustrator Results without filters following selection of an activity

\section{Activity}

Vegetable farming

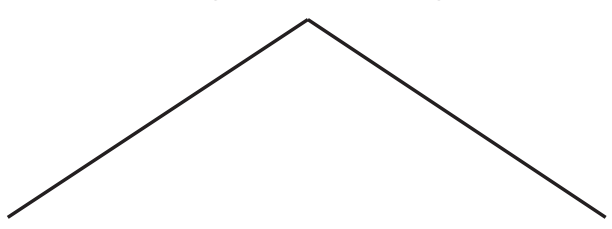

Contaminant 1

Nitrate

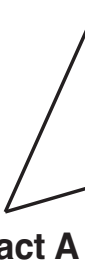

Impact A

Decline in water

Quality

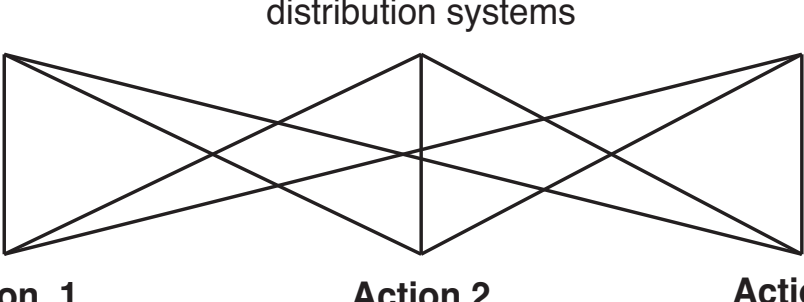

Action 1

Reduce the spread of fertilizer

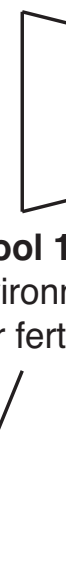

Actor A

Farmer

Action 2

Reduce the

spread of

de-icing salt

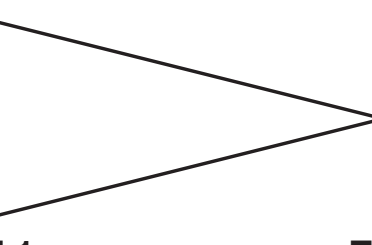

Salt Management Plan

Contaminant 2

Phosphate

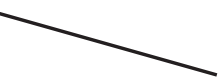

Impact C

Destruction

of the flora

Corrosion of

drinking water

Action 3

Manage

agricultural

waste

plan for fertilizers
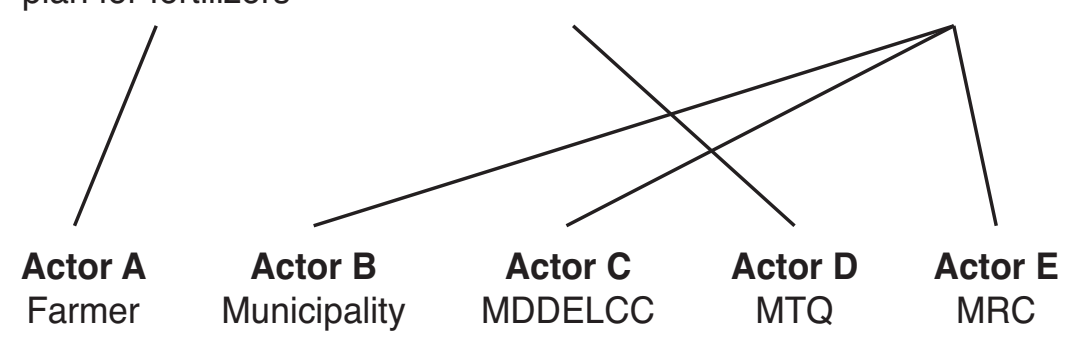

\section{Agroenvironmental}

Results with filters following serkeretionnlo of an activity

Activity

Vegetable farming

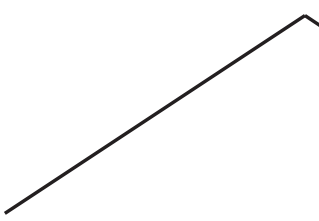

Contaminant 1

Nitrate

Contaminant 2

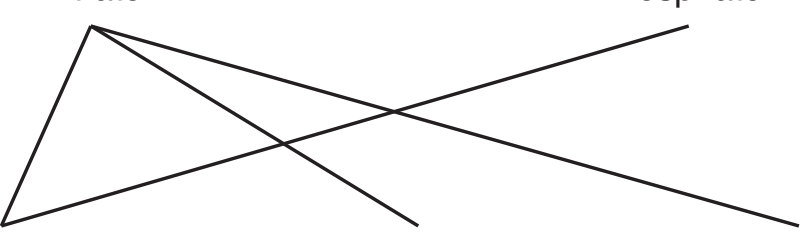

Impact A

Decline in water

Quality

Impact B

Corrosion of

drinking water

distribution systems

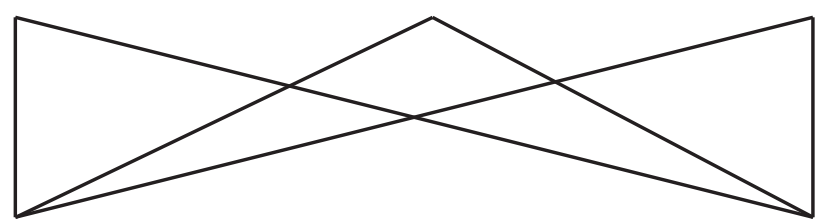

\section{FILTER}

Action 1

Reduce the

spread of fertilizer

Action 3

Manage

agricultural

waste

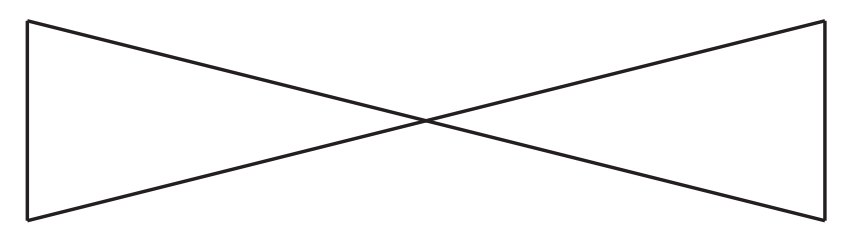

\section{Tool 1}

Agroenvironmental

plan for fertilizers

Sensibilisation

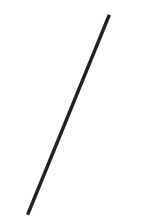

Actor A

Farmer

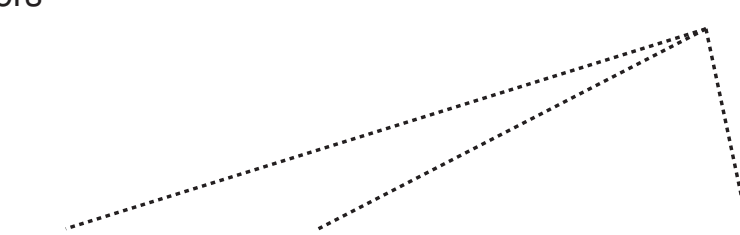

FILTER
Actor B

Municipality
Actor C

MDDELCC
Actor E MRC 


\begin{tabular}{|l|l|}
\hline Actor & Description \\
\hline Attribute & Number identifying the actor \\
\hline ID_Actor & Name of the actor/stakeholder \\
\hline Name_Actor &
\end{tabular}

\begin{tabular}{|l|l|}
\hline Action & Description \\
\hline Attribute & Number identifying the action \\
\hline ID_Action & Name of the action \\
\hline Name_Action &
\end{tabular}

\section{Activity}

\section{Attribute}

ID_Activity

Category_CUBF

Code_CUBF

Name_Activity

\section{Description}

Number identifying the activity Name of the CUBF category MEFQ code identifying the activity

Name of the activity

\section{Impact}

\section{Attribute}

ID_Impact

Type_Impact

Name_Impact

\section{Description}

Number identifying the impact

Identify the type of the impact that could occur (environnemental, infrastructure, etc.)

Name of the impact

\begin{tabular}{|c|c|}
\hline \multicolumn{2}{|l|}{ Contaminant } \\
\hline Attribute & Description \\
\hline ID_Contaminant & Number identifying the contaminant \\
\hline Name_Contaminant & Name of the contaminant \\
\hline Max_Concentr_Accept & $\begin{array}{l}\text { Indicates the maximum concentration of } \\
\text { contaminant that is acceptable to be found } \\
\text { in water as defined by current legislation }\end{array}$ \\
\hline Aesthetic_Obj & $\begin{array}{l}\text { Indicates the aesthetic indicators for water } \\
\text { as defined by Health Canada }\end{array}$ \\
\hline Molecular_Form & $\begin{array}{l}\text { Identicates the molecular formula of the } \\
\text { contaminant }\end{array}$ \\
\hline Seuil_Naturel & $\begin{array}{l}\text { Indicates the natural concentration of } \\
\text { contaminant in water }\end{array}$ \\
\hline
\end{tabular}

\section{Tool}

Attribute

ID_Tool

Name_Tool

\section{Description}

Number identifying the tool

Name of the tool 


\begin{tabular}{|l|l|}
\hline Reference & Description \\
\hline Attribute & Number identifying the reference \\
\hline ID_Reference & $\begin{array}{l}\text { Indicates the type of the document used } \\
\text { as a reference (law, land-use planning } \\
\text { document, etc.) }\end{array}$ \\
\hline Type_Document & $\begin{array}{l}\text { Name of the document in wich is proposed } \\
\text { the action or a similar one }\end{array}$ \\
\hline Name_Author & $\begin{array}{l}\text { Name of the author (MRC, OBV, } \\
\text { Municipalities, etc.) of the document used } \\
\text { as a reference }\end{array}$ \\
\hline Date_Document & $\begin{array}{l}\text { Indicates the date of ratification or } \\
\text { production of the document }\end{array}$ \\
\hline
\end{tabular}

\section{Recurrence}

\section{Attribute}

ID_Frequency

Frequency_Name

\section{Description}

Number identifying the frequency

Definition of the temporality

\section{Risk}

\begin{tabular}{|l|l}
\hline Attribute & \\
\hline ID_Risk & \\
\hline Codification_Risk & \\
\hline Color_Risk & \\
\hline
\end{tabular}

Description

Number identifying the risk

Degree of risk from low to very high

Color related to a degree of risk

\begin{tabular}{|l|l|}
\hline Toxicity & Description \\
\hline Attribute & Number identifying the toxicity \\
\hline ID_Toxicity & $\begin{array}{l}\text { Number linking the tool with PACES } \\
\text { Protocol 23 }\end{array}$ \\
\hline Ponderation_PACES & $\begin{array}{l}\text { Toxic product in greater quantity in the } \\
\text { contaminant }\end{array}$ \\
\hline Tox_1st_Product & $\begin{array}{l}\text { Toxic product in medium quantity in the } \\
\text { contaminant }\end{array}$ \\
\hline Tox_2nd_Product & $\begin{array}{l}\text { Toxic product in lowest amount in } \\
\text { contaminant }\end{array}$ \\
\hline Tox_3rd_Product
\end{tabular}

\section{Quantity}

\section{Attribute}

ID_Quantity

Ponderation_PACES

Quantity_Product

Concentration

\section{Description}

Number identifying the quantity

Number linking the tool with PACES

Protocol 23

Quantity of rejected contaminant

Concentration of rejected contaminant

\begin{tabular}{|l|}
\hline Zone \\
\hline Attribute \\
\hline ID_Impact_Zone \\
\hline Name_Impact_Zone \\
\hline
\end{tabular}

\section{Description}

Number identifying the impact zone

Indicates the impact area 
Appendix 2 - Adobe Illustrator

\begin{tabular}{|l|l|}
\hline Actor & Description \\
\hline Attribute & Primary Key \\
\hline ID_Actor & Text \\
\hline
\end{tabular}

\section{Action}

\begin{tabular}{|l|l|}
\hline Attribute & Description \\
\hline ID_Action & Primary Key \\
\hline Name_Action & Text \\
\hline
\end{tabular}

\begin{tabular}{|l|l|}
\hline Activity & Description \\
\hline Attribute & Primary Key \\
\hline ID_Activity & Text \\
\hline Category_CUBF & Numerical \\
\hline Code_CUBF & Text \\
\hline Name_Activity &
\end{tabular}

\begin{tabular}{|l|l|}
\multicolumn{2}{|l|}{ Impact } \\
\hline Attribute & Description \\
\hline ID_Impact & Primary Key \\
\hline Type_Impact & Text \\
\hline Name_Impact & Text \\
\hline
\end{tabular}

\section{Contaminant}

\begin{tabular}{|l|l|}
\hline Attribute & Description \\
\hline ID_Contaminant & Primary Key \\
\hline Name_Contaminant & Text \\
\hline Max_Concentr_Accept & Text \\
\hline Aesthetic_Obj & Text \\
\hline Molecular_Form & Text \\
\hline Seuil_Naturel & Text \\
\hline
\end{tabular}

Tool
\begin{tabular}{|l|l|}
\hline Attribute & Description \\
\hline ID_Tool & Primary Key \\
\hline Name_Tool & Text \\
\hline
\end{tabular}

\begin{tabular}{|l|l|}
\hline Reference Click here to download Supplementary Material Appendix2.ep\$ & Description \\
\hline Attribute & Primary Key \\
\hline ID_Reference & Text \\
\hline Type_Document & Text \\
\hline Name_Document & Text \\
\hline Name_Author & Date \\
\hline Date_Document & \\
\hline
\end{tabular}

\begin{tabular}{|l|l|}
\hline Toxicity & \\
\hline Attribute & Description \\
\hline ID_Toxicity & Primary Key \\
\hline Ponderation_PACES & Numerical \\
\hline Tox_1st_Product & Multiple Choice List \\
\hline Tox_2nd_Product & Multiple Choice List \\
\hline Tox_3rd_Product & Multiple Choice List \\
\hline
\end{tabular}

\begin{tabular}{|l|l|}
\hline \multicolumn{2}{|l|}{ Quantity } \\
\hline Attribute & Description \\
\hline ID_Quantity & Primary Key \\
\hline Ponderation_PACES & Numerical \\
\hline Quantity_Product & Text \\
\hline Concentration & Multiple Choice List \\
\hline
\end{tabular}

\begin{tabular}{|l|l|}
\hline Zone \\
\hline Attribute & Description \\
\hline ID_Impact_Zone & Primary Key \\
\hline Name_Impact_Zone & Text \\
\hline
\end{tabular}

\begin{tabular}{|l|l|}
\hline \multicolumn{2}{|l|}{ Recurrence } \\
\hline Attribute & Description \\
\hline ID_Frequency & Primary Key \\
\hline Frequency_Name & Text \\
\hline
\end{tabular}

\begin{tabular}{|l|l|}
\hline \multicolumn{2}{|l|}{ Risk } \\
\hline Attribute & Description \\
\hline ID_Risk & Primary Key \\
\hline Codification_Risk & Text \\
\hline Color_Risk & Text \\
\hline
\end{tabular}




\section{Action name}

Effective management of septic tank sludge

Encourage a sustainable land-use development

Ensure compliance with rules for storage of fertilizer / toxic products

Ensure compliance with various wastewater disposal regulations for isolated / unconnected residences

Ensure proper drainage of septic systems

Establish preservation areas to protect the most vulnerable areas and wetlands

Geolocation of individual septic systems

Identify strategic locations for snow deposits

Implement sustainable forest management

Integrate new developments within the municipal sewer system

Manage agricultural waste

Monitor lake water quality

Raise awareness about how to store, use and dispose of hazardous household waste

Raise awareness of good practices in the use of fertilizers

Raise public awareness of good practices in septic tank maintenance

Reduce fertilizer input in lakes and streams

Reduce the spread of de-icing salt

Reduce the spread of fertilizer

Reduce the spread of pesticides

Rehabilitate contaminated soils

Require raw material industries to periodically conduct soil quality surveys within harvested areas

Restoration of contaminated lakes and streams (mechanical, physical, chemical, biological)

Restore natural sites that have undergone a modification following an industrial activity

Set up flood barrier to retain and filter contaminated water 


\section{Citizens}

Commission de la Protection du Territoire Agricole du Québec (CPTAQ) [Commission for the Protection of Agricultural Land in Quebec]

Conseil régional de l'environnement (CRE) [Regional environmental council]

Eco-centers

Farmer

Ministère des Forêts, de la Faune et des Parcs (MFFP) [Ministry of Forests, Wildlife and Parks]

Ministère des transports du Québec (MTQ) [Quebec Ministry of Transportation]

Ministère du Développement durable, de l'Environnement et de la Lutte contre les changements climatiques (MDDELCC) [Quebec Environment Ministry]

Municipalités régionales de comté (MRC) [Regional county municipalities]

Municipalities

Non-profit organizations

Organismes de Bassins versant (OBV) [Watershed organizations]

Private organizations

Promoters

Public administrations

Resident associations 
Anti-agglomeration additives (de-icing salts)

Anticorrosive Additives

Bore

Calcium chloride (de-icing salts)

Chromium, chromate (de-icing salts)

Coliform and non-coliform bacteria

\section{Copper}

Ferric ferrocyanide (de-icing salts)

\section{Fertilizer}

\section{Food oils}

Herbicides

Highly corrosive acids

Iron

Lixiviate

Manganese

Metals

Mineral and metal sulphides

Mineralized Waters

Molybdenum

\section{Nitrate}

Nitrogen

Oils

Organic and inorganic chemical contaminants

Pesticides (especially against mosquitoes, ticks, ants) and other pesticides

Phosphate
Sodium (de-icing salts)

Sodium ferrocyanide (de-icing salts)

Soluble potash

Solvents

Waste from farmed sewage

Waste from households and businesses

Waste water

Zinc 


\begin{tabular}{|c|c|}
\hline Impact type & Impact name \\
\hline Environment & Animal Infertility \\
\hline Public health & Articulation pain and deformity \\
\hline Public health & Cancer (all types) \\
\hline Infrastructure & Corrosion of drinking water distribution systems \\
\hline Infrastructure & Corrosion of road infrastructure \\
\hline Material goods & Corrosion of vehicles \\
\hline Environment & Decline in water quality (taste and odor) \\
\hline Environment & Destruction of the flora \\
\hline Public health & Diarrhea \\
\hline Public health & Disruption of thyroid function \\
\hline Public health & Effect on reproduction (testicular atrophy and spermatogenesis) \\
\hline Environment & Eutrophication \\
\hline Public health & Fever \\
\hline Public health & Increased risk of cancer \\
\hline Public health & Liver dysfunction \\
\hline Environment & Loss of aquatic fauna \\
\hline Public health & Methemoglobinemia (blue baby syndrome) \\
\hline Public health & Nausea \\
\hline Public health & Neurological complications \\
\hline Infrastructure & Obstruction of drinking water distribution systems \\
\hline Public health & Respiratory complications \\
\hline Public health & Skin irritation \\
\hline Environment & Uncontrolled growth of certain aquatic species (algae, duckweed) \\
\hline Public health & Vitamin deficiency \\
\hline Public health & Vomiting \\
\hline
\end{tabular}


Tool name

Agro environmental plan for fertilizers

Pesticide management code

Advice and expertise

Sustainable forest management Act

Protection of agricultural land and agricultural activities Act

Land-use development plan (Plan d'aménagement d'ensemble)

Implementation and architectural integration plan (Plan d'implantation et d'intégration architecturale)

Master plan (Plan d'urbanisme)

Environmental management plan for road salts (Plan de gestion environnementale des sels de voirie)

Special urban planning (Plan particulier d'urbanisme)

Soil Protection and Contaminated Land Reclamation Policy

City policy

Special projects for the construction, alteration or occupancy of a building

Regulation respecting municipal agreements

Zoning regulations

Sewage disposal and wastewater treatment regulations

Regulation respecting quarries and sand pits with respect to soil restoration

Snow removal site regulations

Municipal pesticide regulation

Voluntary lakes surveillance network

Land-use planning and development plan

Awareness raising 


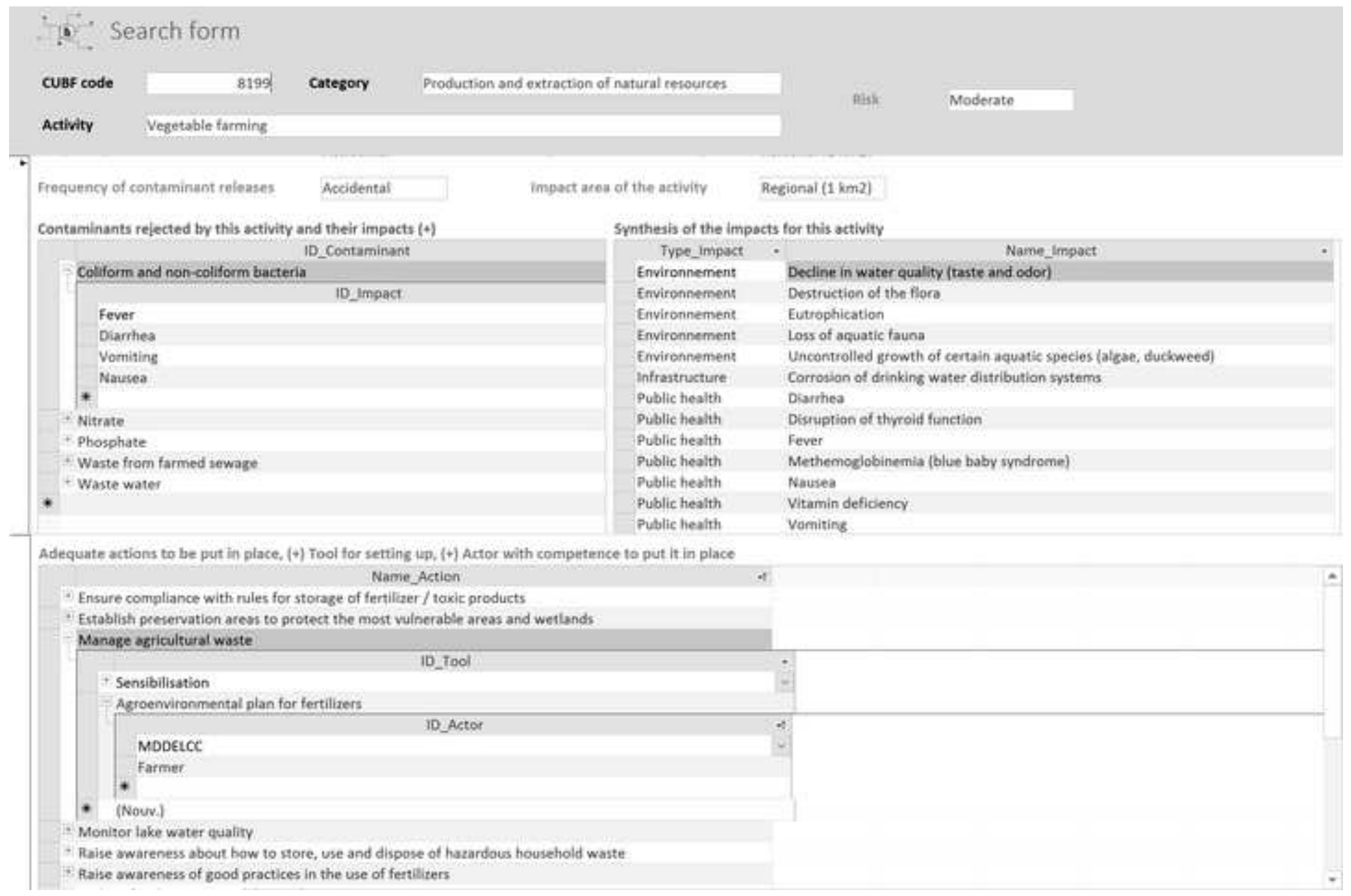

Synthesis of the impocts for this activity

setting up, ( i) Artor with competence to put it in place 